\title{
PERLINDUNGAN HUKUM TERHADAP TERSANGKA PADA TAHAP PENYIDIKAN YANG TDAK SESUAI DENGAN PASAL 52 KITAB UNDANG- UNDANG HUKUM ACARA PIDANA (contoh kasus: penangkapan tersangka pemilik ribuan rokok illegal)
}

\author{
Andri Tjhin \\ (Mahasiswa Program S1 Fakultas Hukum Universitas Tarumanagara) \\ (E-mail: Andri_tjhin@yahoo.com)

\section{Mety Rahmawati} \\ (Corresponding Author) \\ (Dosen Hukum Pidana Fakultas Hukum Universitas Tarumanagara, Meraih Gelar Sarjana dari \\ Fakultas Hukum Universitas Trisakti, Magister Hukum Dari Fakultas Hukum Universitas \\ Tarumanagara, dan Doktoral Hukum Dari Universitas Trisakti ) \\ (E-mail: Metyargo@yahoo.com)
}

\begin{abstract}
Human rights are the rights attached to every individual and recognized by international law, in practice regarding human rights is regulated to become more specific, namely being the right of the suspect. The KUHAP regulates the rights of suspects precisely in Article 50 until 68. In the case of writing this scientific paper, there are several suspect rights in the stage of investigations that are violated by law enforcement officers, especially article 52, which means there are differences between those stipulated in the law with reality. The research method used is a normative legal research method which is based on primary, secondary, and supported by the results of interviews with related professions, which are then analyzed deductively. The results of this study illustrate that there is legal uncertainty amid law enforcement in Indonesia. Theory of justice, Theory of legal protection and the theory of legal certainty used which essentially becomes a benchmark for conformity of law enforcement in Indonesia.
\end{abstract}

Keywords: legal protection, suspect right, investigation. 


\section{PENDAHULUAN}

\section{A. Latar Belakang}

Dalam sejarah peradaban manusia di muka bumi ini kita mengenal apa yang di sebut dengan hak asasi manusia, yang dapat kita artikan sebagai hak yang melekat kepaa setiap orang atau individu sebagai manusia seutuhnya yang diberikan oleh tuhan yang tidak bisa dicabut kembali oleh siapapun atau dengan alasan apapun. Kita melihat HAM sebagai suatu yang penting dan mendasar dalam menjaga kehidupan yang manusiawi dan yang paling berharga adalah hak untuk menjadi manusia seutuhnya. Dalam era globalisasi ini perlindungan HAM bagi pelaku tindak pidana menjadi penting karena negara memiliki tanggung jawab terhadap individu sebagai tersangka ataupun terdakwa untuk tidak mendapatkan perlakuan hukum yang sewenang - wenang yang bertentangan dengan hak dasar manusia yang telah melekat tersebut.

Hak asas manusia adalah sesuatu yang sangat mendasar dan sangat penting bagi pedoman kehidupan umat di muka bumi ini. Hak yang sudah ada dan melekat pada setiap individu yang tidak dapat di ganggu oleh orang lain apa lagi di hilangkan keberadaan dari hak tersebut oleh orang lain. Oleh sebab itu, hak ini sangat penting dan harus dipahami oleh setiap individu dank arena sangat penting sampai di jadikan pelajaran dalam program pendidikan di Indonesia mulai dari sekolah dasar sampai perguruan tinggi untuk menekankan kepada setiap warga negara tentang hak tersebut.

Sudah 68 tahun semenjak ditetapkannya Universal Declaration of Human Rights (UDHR) atau Deklarasi Universal Hak Asasi Manusia (DUHAM) 1948, manusia hidup dalam kebebasan, persamaan dan perlindungan. Setiap orang diakui hak dasarnya. Hal ini mengharuskan bagi semua orang tanpa terkecuali untuk mengakui hak dasar atau kodrati orang lain, termasuk negara beserta penguasanya sekalipun tanpa terkecuali. Sebagaimana yang diungkapkan oleh Muhtaj, "DUHAM adalah puncak konseptualisasi HAM universal", artinya isi 
DUHAM berlaku untuk semua bangsa di dunia tanpa kecuali, termasuk juga untuk bangsa Indonesia. Indonesia adalah negara yang sudah mendeklarasikan kemerdekaan 3 tahun lebih dahulu sebelum ditetapkan DUHAM 1948. Pada dasarnya negara Indonesia sangat memperhatikan penegakan HAM. Dalam upaya memberikan jaminan atas penegakan HAM, materi muatan HAM dimasukkan dalam Amandemen Kedua 12 dan UUD 1945. Di dalam Pembukaan UndangUndang Dasar 1945 juga terdapat ketentuan mengenai HAM.

Setiap negara bertanggung jawab terhadap hak asasi tiap warga negaranya. Sebagaimana dalam Pasal 71 UU RI Nomor 39 Tahun 1999 tentang Hak Asasi Manusia sebagai berikut: Pemerintah wajib dan bertanggung jawab menghormati, melindungi, menegakkan, dan memajukan hak asasi manusia yang diatur dalam Undang-undang ini, peraturan perundang-undangan lain, dan hukum internasional tentang hak asasi manusia yang diterima oleh Negara Republik Indonesia. Pemerintah dan aparatur penegak hukum harus menjaga hak asasi orang lain dan tidak boleh lepas tanggung jawab terhadap hak dari pada subjek hukum. Tidak boleh membiarkan begitu saja dan lepas tanggung jawab terhadap hak asasi tiap warga negaranya. Sebisa mungkin penegakan hukum di idonesia harus seusai dengan konstitusi. Pembiaran terhadap hak asasi warga negara dapat dikatakan sebagai pelanggaran HAM.

Secara keseluruhan penduduk dunia dan menghargai hak yang di sebut dengan hak asasi manusia yang mendasar. Hak-hak tersebut melekat ke dalam diri manusia, bahkan membentuk harkat itu sendiri sebagaimana yang ditegaskan dalam pembukaan Universal Declaration of Human Rights (UDHR). UDHR antara lain mengakui dan melindungi hak setiap orang dari penangkapan dan penahanan secara sewenang-wenang, setiap orang dianggap tidak bersalah sampai dibuktikan secara sah mereka bersalah, setiap orang tidak boleh diganggu privasinya, keluarganya, rumah, dan surat-menyuratnya. Jika hak asasi yang diberikan kepadanya berdasarkan undang-undang dilanggar, maka harus ada upaya yang dapat memulihkan haknya melalui pengadilan. 
Sejak mulai diberlakukannya Kitab Undang-Undang Hukum Acara Pidana (KUHAP) di Indonesia, para tersangka/terdakwa diberikan hak untuk melindungi dirinya dari kesewenangan aparat penegak hukum. Adapun sebagian hak yang diatur dalam KUHAP, yaitu: hak untuk memberikan keterangan secara bebas kepada penyidik atau hakim (Pasal 52 KUHAP), hak untuk mendapatkan bantuan hukum pada waktu dan setiap tingkat pemeriksaan (Pasal 54 KUHAP), hak untuk mengusahakan saksi yang meringankan (Pasal 65 KUHAP), dan hak untuk tidak dibebani pembuktian (Pasal 66 KUHAP). Ada juga asas hukum yang kita kenal dengan asas praduga tidak bersalah. Asas praduga tidak bersalah itu mencerminkan prisip hukum kita yaitu prinsip akusatur atau dengan kata lain bisa manusia atau tersangka di anggap sebagai subjek bkan objek. Prinsip ini dapat dijadikan dudukan posisi tersangka di tingkat pemeriksaan yang membuat tersangka harus diperlakukan secara manusiawi yang mempunyai harkat martabat dan harga diri, yang menjadi objek dalam tingkat pemeriksaan adalah kesalahan atau tindakan yang dilakukan oleh seseorang yang bertentangan atau di langgar oleh undang- undang. Oeh karena itu ada yang namanya pemeriksaan.

Tersangka dalam memberikan keterangan kepada penyidik harus dalam keadaan yang tenang tanpa tekanan dan paksaan untuk mengakui sebuah perbuatan yang tidak dikehendakinya. Dalam hal tersangka memberikan keterangan tentang apa yang sebenarnya terjadi sehubungan dengan tindak pidana yang dipersangkakan kepadanya, penyidik mencatat dalam berita acara dengan seteliti-telitinya sesuai dengan kata yang dipergunakan oleh tersangka sendiri (Pasal 117 Ayat (1) dan (2) KUHAP). Tetapi sangat di sanyangkan tidak ditemukan sanksi bagi pelanggar dalam pasal 117 tersebut, jaminan akan hal itu hanya dapat dilakukan melalui prapradilan dengan mengajukan gugatan ganti rugi 
atas dasar alasan pemeriksaan telah dilakukan tanpa alasan yang berdasarkan undang-undang. ${ }^{1}$ )

Hukum yang sekarang berlaku di Indonesia yaitu kitab undang-undang hukum acara pidana sebenarnya sudah meletakan secara tegas hak hak tersangka di dalam nya, jauh lebih baik di banding hukum yang berlaku pada say penjajahan belanda atau yang kita kenal dengan HIR. Tetapi walaupun sudah datur sedemikian rupa dalam hal penegakan hukum di Indonesia masih sering dijumpai ketidak sesuaian pelaksanaan hukum tersebut terutama dalam tahapan penyidikan, penyelidikan, dan persidangan. Beberapa tindakan yang sering ditemui mencerminkan bahwa penegakan hukum terkadang masi cenderung ke sistem inquisitor. Sistem tersebut adalah sistem yang dalam penegakannya meletakan kedudukan tersangka sebagai objek, dipaksa mengakui kesalahanya dengan dasar pengakuan tersebut sudah bisa mendapatkan titik terang kalua seseorang memang berbuat melanggar aturan atau tidak sesuai dengan hukum yang berlaku, sistem seperti ini dianggap cenderung melanggar ham dan memiliki nilai keadilan yang rendah. Tindakan yang menyimpang yang dimaksud adalah tindakan kekerasan pemaksaan dalam bentuk fisik maupu psikis yang sering didapatkan oleh seorang tersangka pada tahap penyidikan yang dilakukan oleh penyidik. Memang dalam KUHAP kita mengenal dengan apa yang di sebut dengan praperadilan tapi lembaga tersebut hanya menguji hal yang bersifat formiil bukan materiil dan ridak memberikan akibat hukum yang tegas bagi pelanggarnya sehingga dirasa kurang cukup kuat untuk menjadi batang tombak pelaksanaan hukum ssesuai dengan aturan yang berlaku. Alasan yuridis atau alasan formiil yang dimaksud adalah seperti penahanan tanpa surat, dan penghentian proses penyidikan tanpa didasari dengan alasan yang kuat dan sah.

Praperadilan memang merupakan sebuah lembaga yang dilahirkan untuk melakukan tindakan pengawasan terhadap aparat penegak hukum dalam

\footnotetext{
${ }^{1)}$ Mohammad Taufik Makarao, Hukum Acara Pidana dalam Teori dan Praktek, (Jakarta: Ghalia Indo, 2002), hal. 30.
} 
melakukan penyidikan agar tidak melakukan kesewenangan dan tidak meyalahgunakan wewenang nya sebagai apartat, oleh sebab itu dalam pelaksanaannya diatur di dalam Kitab Undang-Undang Hukum Acara Pidana (KUHAP). Kegiatan Penyidik yang implementasinya dapat berupa, misalnya penangkapan bahkan penahanan, maka hukum acara pidana melalui ketentuan ketentuan yang sifatnya memaksa menyingkirkan asas yang diakui secara universal yaitu hak kebebasan seseorang.dalam hukum acara pidana di Indonesia para penegak hukum telah diberi kedudukan serta jelas kewenangannya dalam melaksanakan amanat undang-undang untuk mencapai ketertibak di dalam masyarakat.

Praperadilan merupakan suatu lembaga yang hanya melakukan peradilan jika ada yang menggugatnya yang dilanggar hak hak nya. Banyaknya permohonan pemeriksaan perkara melalui praperadilan karena untuk mewujudkan keadilan sebelum perkara dilanjutkan ke Pengadilan Negeri. Pasal 82 ayat (1) huruf d KUHAP menyatakan dalam hal suatu perkara sudah mulai diperiksa oleh Pengadilan Negeri, sedangkan pemeriksaan mengenai permintaan kepada praperadilan belum selesai, maka permintaan tersebut dinyatakan gugur. Tidak semuanya putusan praperadilan dapat dimenangkan oleh tersangka atau pihak yang mengajukan dalam proses sidang pemeriksaan praperadilan. Adapun salah satu contoh kasus adalah praperadilan yang diajukan oleh seorang yang disangka melakukan tindak pidana korupsi terhadap status penetapan tersangka yang telah ditetapkan oleh penyidik, dimana dalam permohonannya pemohon mengajukan gugatan praperadilan yang menjadi objek dalam praperadilan ini adalah sah tidaknya penetapan tersangka.

Sangat penting peran suatu lembaga pengawasan dalam suatu negara untuk mengawasi proses penegakan hukum. Sebenarnya secara otomatis pengawasan atau control terhadap aparat itu sudah ada dalam setiap lembaga dimana penegak hukum tersebut ada. Tetapi, pengawasan semacam ini dirasa tidak cukup berpengaruh karena masih sangat tergantung dari intelektual dari setiap individu 
internal lembaga itu sendiri tanpa dimungkinkanya ada campur tangan atau bentrok kepentingan dari pihak luar. Kekerasan dan pemaksaan terhadap tersangka/terdakwa dalam penyidikan sangat sulit dibuktikan.apalagi seringkali kekerasan fisik atau intimidasi yang diterima tersangka tidak menimbulkan bekas luka, salah satu contohnya kekerasan secara psikis. Berdasarakan hal tersebut, harus diakui bahwa KUHAP yang melalui lembaga prapradilan kurang menjangkau hak tersangka yang dilanggar oleh para petugas penyidik.

Dalam penulisan ini, Penulis juga menyertakan contoh kasus kesewenangan petugas dalam melaksanakan penyidikan disertai dengan putusan Praperadilan No. 10/Pid.Prap/2016/PN.SMG, yaitu kasus seorang tersangka pemilik ribuan batang rokok ilegal berinisial S (28), tersangka pemilik rokok tanpa cukai yang ditangkap oleh petugas bea cukai di Semarang mendapat kekerasan dari petugas bea cukai, bukan hanya kekerasan fisik yang didapatkannya, dia juga mendapatkan paksaan dalam memberikan pengakuan di Berita Acara Pemeriksaan (BAP), penangkapannya pun tidak disertai surat penangkapan yang resmi.

Dalam kronologi singkat contoh kasus tersebut terlihat bahwa hak-hak tersangka tidak terpenuhi sebagaimana yang diatur dalam KUHAP, banyak aparat yang bertindak sewenang-wenang terhadap tersangka menggambarkan bahwa aparat penegak hukum yang menegakan hukum masih tidak mengikuti aturan yang ada yang tertuang dalam KUHAP. Penyidik dalam melaksanakan tugasnya dalam proses penyidikan, penyidik diberikan kewenangan oleh Undang-Undang. Dalam KUHAP diatur kewenangan penyidik dalam Pasal 7 KUHAP.

Berdasarkan uraian tersebut di atas, untuk mendalami dan menuangkan contoh kasus tersebut maka diangkatlah proposal penulisan skripsi dengan judul: "Perlindungan Hukum Terhadap Tersangka pada Tahap Penyidikan yang Tidak Sesuai dengan Pasal 52 Kitab Undang-Undang Hukum Acara Pidana (contoh kasus: penangkapan tersangka pemilik ribuan rokok illegal)”.

\section{B. Rumusan masalah}


Berdasarkan uraian dari latar belakang yang di sampaikan, maka rumusan masalah yang hendak diteliti adalah:

1. Bagaimana perlindungan hak tersangka pada tahap penyidikan yang sesuai dengan Pasal 52 Kitab Undang-Undang Hukum Acara Pidana?

\section{Metode Peneltian}

Metode penulisan sangat penting karena keerhasilan dari suatu penulisan ditentukan oleh metode yang digunakan. Agar mendapatkan data-data yang dapat dipertanggungjawabkan, metode penulisan merupakan suatu unsur mutlak yang harus ada dalam penulisan hukum ini. Menurut Soerjono Soekanto, metodologi merupakan suatu unsur yang mutlak harus ada di dalam penelitian dan pengembangan suatu ilmu pengetahuan. ${ }^{2)}$ Adapun metode-metode yang digunakan penulis dalam proposal ini adalah sebagai berikut:

1. Jenis Penelitian

Jenis penelitian yang digunakan dalam penelitian ini adalah jenis penelitian Hukum Normatif, yakni penelitian yang dilakukan dengan cara meneliti dan menganalisis bahan-bahan pustaka yang lazimnya dinamakan data sekunder. ${ }^{3)}$

2. Metode Penelitian

Di dalam penelitian hukum terdapat beberapa pendekatan. Dengan pendekatan tersebut, peneliti akan mendapatkan informasi dari berbagai aspek mengenai isu yang sedang diteliti untuk mencari jawabannya. Berdasarkan pada permasalahan yang diteliti oleh penulis, maka metode pendekatan yang digunakan dalam

\footnotetext{
${ }^{2)}$ Soerjono Soekanto, Pengantar Penelitian Hukum, (Jakarta: UI Press, 2003), hal. 7.

${ }^{3)}$ Soerjono Soekanto, Penelitian Hukum Normatif Suatu Tujuan Singkat, (Jakarta: RajaGrafindo Persada, 2006), hal. 12.
} 
penulisan ini adalah pendekatan undang-undang, yaitu metode atau cara yang digunakan didalam penelitian hukum yang dilakukan dengan cara menelaah semua undang-undang dan regulasi yang berkaitan dengan isu hukum yang sedang diteliti.

3. Jenis dan Sumber Data

1. Jenis Data

Jenis data yang digunakan dalam penelitian ini adalah data sekunder. Data sekunder adalah data yang diperoleh melalui bahan kepustakaan

2. Sumber Data

1) Bahan Hukum Primer

Bahan hukum primer merupakan bahan hukum yang mengikat atau yang membuat orang taat pada hukum seperti Peraturan Perundang-undangan dan putusan haim, bahan hukum primer yang penulis gunakan dalam penulisan ini yakni, Kitab Undanng-undang Hukum Acara Pidana Nomor 8 Tahun 1981, Peraturan Kapolri Nomor 14 Tahun 2012 tentang Manajemen Penyidikan Tindak Pidana.

2) Bahan Hukum Sekunder

Bahan hukum sekunder diartikan sebagai bahan hukum yang tidak mengikat tetapi bahan hukum yang memberikan penjelasan mengenai bahan hukum primer yang mempelajari suatu bidang tertentu secara khusus yang akan memberikan pertunjuk kemana penelitian akan mengarah. Bahan sekunder yang dimaksud oleh peneliti adalah doktrin-doktrin yang ada dalam buku maupun dalam jurnal hukum tentang Pertanggungjawaban dalam Hukum Pidana.

3) Bahan Non Hukum

Bahan non hukum yaitu bahan yang mendukung dan memberikan penjeasan atau petunjuk dan informasi terhadap bahan hukm primer dan sekunder dengan memberikan pemahaman dan 
pengertian lebih luas mengenai obyek yang diteliti. Bahan non hukum yang digunakan oleh peneliti adalah Kamus Besar Bahasa Indonesia.

\section{Teknik Pengumpulan Data}

Dalam penulisan ini teknik pengumpulan data yang dipergunakan adalah studi kepustakaan. Studi kepustakaan adalah segala usaha yang dilakukan oleh peneliti untuk menghimpun informasi yang relevan dengan topik atau masalah yang akan atau sedang diteliti dengan cara meneliti bahan pustaka atau yang disebut dengan data sekunder. Informasi itu dapat diperoleh dari buku-buku ilmiah, laporan penelitian, artikel, karangan ilmiah, tesis, dan disertasi serta wawancara.

\section{Teknik Analisis Data}

Adapun bahan hukum yang diperoleh dalam penelitian diuraikan dan dihubungkan sedemikian rupa, sehingga disajikan dalam penulisan yang lebih sistematis guna menjawab permasalahan yang telah dirumuskan. Analisis yang digunakan bersifat kualitatif normative, artinya data yang digunakan telah memperoleh atau dianalisis berdasarkan norma-norma hukum yang ada sebagai norma hukum positif.

hal ini dapat dilakukan dengan cara: ${ }^{4)}$

a. Evaluatif yaitu melakukan penilaian atau mengevaluasi tepat atau tidak tepat, benar atu tidak benar, suatu pandangan, pernyataan rumusan norma, keputusan baik yang tertera dalam bahan hukum primer, bahan hukum sekunder, maupun bahan hukum tersier.

\footnotetext{
${ }^{4)}$ I Made Pasek Diantha, Metodologi Penelitian Hukum Normatif, (Jakarta: Prenada Media Group, 2016), hal. 152.
} 
b. Interpretatif yaitu menggunakan jenis penafsiran menurut perundangundangan.

c. Argumentatif yaitu penilaian berdasarkan pada alasan-alasan yang bersifat penalaran hukum.

\section{PEMBAHASAN}

\section{A. Hasil Penelitian}

Kasus yang saya ambil untuk menjadi contoh kasus dalam penulisan skripsi saya adalah kasus yang menimpa seorang tersangka berinisial S di Semarang yang mengalami penculikan dan penganiayaan yang dilakukan terhadap tersangka oleh penyidik. Terdapat pula kejanggalan dalam kasus tersebut karena tersangka berinisial $\mathrm{S}$ tersebut sebelumnya di tangkap oleh petugas pada tanggal 5 September 2016 di rumahnya di Desa Bermi Kabupaten Demak bersama barang bukti 850 ribu batang rokok illegal, namum surat penangkapan pun baru muncul keesokan harinya tertanggal 6 September 2016.

Merasa tidak diperlakukan dengan baik dan di jebak oleh penyidik, seperti beberapa tindak kekerasan yang dialami dan tekanan saat BAP, maka tersangka berinisial $\mathrm{S}$ tersebut menggugat praperadilan. Dalam persidangan terungkaplah penggeledahan yang dilakukan tanpa didampingi 2 orang saksi serta penyitaan yang tidak dibuatkan berita acara dan hakim pun mengabulkan gugatan pemohon untuk seluruhnya, memerintahkan termohon untuk segera mengeluarkan pemohon dari tahanan. Hakim juga berpendapat pemohon tidak bisa dikategorikan sebagai tersangka karena tidakadanya surat penetapan tersangka yang sah dan oleh karena itu tersangka tidak bisa di tahan. Sementara itu kuasa hukum tersangka, mengatakan dengan adanya putusan tersebut kliennya harus segera di keluarkan dari tahanan, pengadilan sudah menyatakan penangkapan dan penahanan tersangka tidak sah. Kuasa hukum tersangka mengatakan bahwa beberapa alasan tersangka mengajukan permohonan tersebut adalah karena ada 
dugaan penculikan dan kekerasan yang dialami oleh tersangka, dalam BAP pun tersangka terpaksa memberikan keterangan di bawah tekanan.

perlindungan merupakan suatu bentuk apresiasi dan implementasi aparat penegak hukum atau juga aparat keamanan untuk menjaga rasa aman baik psikis maupun fisik, kepada orang atau subjek hukum, dari intimidasi, gangguan, terror, dan kekerasan dari pihak mana pun, yang diberikan pada tahap penyelidikan, penyidikan, penuntutan, dana tau pemeriksaan di sidang pengadilan.

Tanpa terkecuali semua warga negara Indonesia harus mendapatkan perlindungan hukum, seperti yang ada pada Undang-Undang Dasar Negara Republik Indonesia Tahun 1945 (UUD 1945), oleh sebab itu semua produk hukum yang di buat oleh dpr bersama dengan pemerintah harus mampu menjamin penerapan atas perlindungan hukum kepada semua orang. Hal itu tercermin dari apa yang telah di tjuangkan dalam undng-undang kita. Penyidik kepolisian ketika melakukan penyelidikan dan penyidikan suatu perkara tindak pidana wajiblah mengumpulkan bukti-bukti tentang suatu tindak pidana yang dimaksud, guna menentukan tersangkanya. Setelah menentukan tersangka tindak pidana, penyidik harus memperhatikan hak-hak tersangka. Berdasarkan UndangUndang Nomor 8 Tahun 1981 tentang Kitab Undang-Undang Hukum Acara Pidana, bahwa tersangka adalah seseorang yang karena perbuatan atau keadaannya, berdasarkan bukti permulaan patut diduga sebagai pelaku tindak pidana.

Penyidik dalam melaksanakan tugasnya diberi wewenang untuk menerima pengaduan ataupun laporan dari seseorang atau korban yang melapor mengenai suatu peristiwa pidana, melakukan langka awal di tempat perkara, memberhentikan orang dan memriksa identitas nya, melakukan penangkapan, penahanan, penggeledahan dan penyitaan dan memeriksa kelengkapan surat surat mengambil gambar dan sidik jari maupun identitas lain memanggil orang untuk di dengar dan diperiksa sebagai saksi atau tersangka, mendatangkan beberapa ahlli yang diperlukan dan berhubungan dengan kepentingan 
pemeriksaan sebuah perkara pidana, menyatakan penghentian proses penyidikan dan melakukan langkah lain menurut hukum yang bertanggung jawab.

Adapun hak tersangka adalah sebagai berikut:

1. Pasal 50 kuhap yang berarti tersangka tidak boleh dibiarkan statusnya terkantung kantung dan harus segera dilimpahkan atau di ajukan ke tahap penuntutan.

2. setelah mendapatkan pemeriksaan dari penyidik maka berhak dimajukan ke proses pengadilan oleh penuntut umum.

3. pasal 51 kuhap dalam proses pemeriksaan seorang tersangka berhak mendapat Bahasa yang jelas dan dimengerti tentang status hukum dan perkara yang disangkakan kepada nya pada waktu pemeriksaan tersebut.

4. Pasal 52 kuhap menjelaskan mengenai tersangka dalam tahap penyidikan mempunyai hak untuk tidak memberikan keterangan dengan tekanan contohnya paksaan intimidasi atau bahkan kekerasan fisik yang dilakukan demi mendapatkan jawaban sesuai dengan keinginan penyidik.

5. pasal 53 kuhap menjamin hak tersangka untuk mendapatkan juru Bahasa apabila terjadi perbedaan penggunaan Bahasa pada tahap penyidikan atau jika seorang tersangka adalah bisu atau tuli maka berlaku pasal 178 .

7. pasal 54 memberikan hak terhadap seorang tersangka untuk mendapatkan bantuan hukum dari para penasihat hukum untuk membantu proses hukum tersangka bahkan dapat memilih sendiri penasihat hukum yang dipercaya oleh tersangka.

8. pasal 56 kuhap memberikan kewenangan bagi seorang tersangka bahkan terhadap pejabat penegak hukum untuk wajib memberikan kepada tersangka yang diancam hukuman 15 tahun hukuman mati ataupun hukuman seumur hidup.

9. pasal 57 kuhap jika seorang tersangka ditahan maka tersangka diperkenankan untuk menghubungi dan meminta bantuan kepada pengacara nya.

10. tersangka berkebangsaan asing berhak untuk menghubungi kepada perwakilan dari negara asaalnya jika dia dikenakan penahanan untuk mengahadapi proses perkaranya. 
11. tersangka juga debirkan hak untuk memnghubungi atau berurusan dengan dokter atau tim medis jika berkaitan dengan kesehatan tersangka baik jika ada hubungan dengan perkaranya ataupun tidak ada hubungannya.

12. keluarga atau orang rumah orang yang bersangkutan juga berhak mendapatkan pemberitahuan atas dengan apa yang dialami berupa penahanan oleh penegak hukum atau pejabat berwenang yang memungkinkan memberikan bantuan kepada tersangka atau memberikan peangguhan kepadanya.

13. keluarga rekan dan kerabat seorang tersangka pun boleh mengunjungi tersangka dan menghubungi untuk penangguhan atau usaha untuk mendapatkan antuan hukum kepada dirinya.

14. baik secara langsung maupun tidak langsung atau dengan perantara tersangka berhak menerima kunjungan demi kepentingan kerja maupun kepentingan urusan kekeluargaan.

15. Tersangka berhak mengirim surat dan menerima surat baik dari penasihat hukum kerabat maupun sanak saudara setiap saat jika diperlukan dan wajib diberikan alat tulis.

16. Tersangka berhak ahli dan pememuka agama yang dipercayainya untuk dimintai keahlian nya demi kepentingan memberikan keterangan yang menguntungkan bagi dirinya pada kasus yang sedang dialami nya.

17. Tersangka tidak boleh dibebankan pembuktkian karena bukan kewajiban.

18. Ganti rugi juga berhak didapatkan tersangka dan rehabilitasi nama baik jika dilakukan beberapa tindakan seperti penahanan penangkapan dan lain nya yang merugikan hak nya dan tidak sesuai dengan aturan acara pidana.

Dari sekian banyak hak tersangka yang diatur dalam KUHAP dalam pasal

52 KUHAP menyatakan bahwa dalam pemeriksaan pada tingkat penyidikan tersangka berhak memberikan keterangan secara bebas kepada penyidik. Tapi sayangnya dalam contoh kasus yang penulis ambil hak tersebut tidak diindahkan oleh penegak hukum ini lah yang memang sering terjadi di lapangan pada penegakan hukum di Indonesia, masih banyak nya ketidak sesuaian antara perilakuk penegakan hukm dengan apa yang seharunya di lakukan seperti yang telah diatur dalam peraturan yang ada, seringkali tersangka di anggap dan diperlakukan sebagai objek bukan sebagai objek, oleh karena itu tersangka 
dipaksa mengaku bersalah bahkan tak jarang di berikan serangan fisik oleh petugas penegak hukum itu sendiri. Seorang penyidik melakukan penyidikan sebelum tahapp penyelidikan guna mengetahui dan menenutkan sebuah kejadian apa yang sesungguhnya terjadi dan setelah itu membuat berita acara serta laporan sesuai dengan apa hasil dari bukti permulaan dalam tahap itu. Penyidikan dapat dilakukan berdasarkan info maupun laporan yang didapati langsung maupun dari orang yang melapor ke anggota penyidik, laporan kepolisian, berita acara pemeriksaan di tempat kejadian, dan berita acara dari hasil pemeriksaan saksi ataupu tersangka. Sedangkan proses penyidikan tindak pidana dilakukan demi mencari keterangan dan bukti untuk memutuskan suatu perkara yang sudah dilaporkan dan diadukan apakah perkara tersebut adalah suatu perkara pidana atau bukan, melengkapi keteragan dan bukti supaya jelas dan bisa segera di proses ke tahap berikutm dan mempersiapkan pelaksanaan penindakan dana tau pemeriksaan.

Sejak tahun 1961 mulai dikenal istilah penyidikan dalam dunia hukum, tepatnya sejak diberlakukan Undang-Undang pokok kepolisian No. 13 Tahun 1961. Istilah pengusutan lebih dikenal sebelumnya yang merupakan istilah dari terjemahan Bahasa Belanda yaitu opsporin.

Pasal 1 butir 2 KUHAP diuraikan bahwa :

"penyidikan adalah serangkaian tindakan penyidik dalam hal dan menurut cara yang diatur dalam undang-undang, mencari dan mengumpulkan bukti yang dengan bukti itu membuat terang tentang tindak pidana yang terjadi dan guna menemukan tersangkanya" Berbicara mengenai penyidikan tidak lain dari membicarakan masalah pengusutan kejahatan atau pelanggaran, orang Inggris lazim menyebutnya dengan istilah "criminal investigation" Tujuan penyidikan adalah untuk menunjuk siapa yang telah melakukan kejahatan dan memberikan pembuktianpembuktian mengenai masalah yang telah dilakukannya. Untuk 
mencapai maksud tersebut maka penyidik akan menghimpun keterangan dengan fakta atau peristiwa-peristiwa tertentu.

Penyidikan biasa dilaksnanakan setelh biasa terjadi suatu peristiwa yang diduga tindak pidana yang melakukan pengumpulan terhadap bukti yang atas daasar bukti tersebut maka akan di usut dan dicari siapa tersangkanya, penyidikan dimulai setelah tindak pidana tersebut terjadi dan untuk mengumpul kan hal hal seperti tindak pidana macam apa, kapan terjadinya suatu tindak pidana, dimana tempat kejadian dilakukan, dengan apa tindak pidana dilakukan, bagaimana tindak pidana dilakukan, apa motiv dasar perbuatan, dan siapa yang melakukan. Proses penyidikan tindak pidana diantaranya adalah penyelidikan, penindakan (pemanggilan, penagkapan, penahanan, penggeledehan, dan penyitaan), pemeriksaan saksi ahli dan tersangka, penyelesaian berkas perkara pembuatan BAP penyerahan dan penyusunan berkas perkara.

Berdasarkan hasil wawancara dengan pihak kepolisian tentang penyidikan :

a) Penyidikan berdasarkan informasi atau laporan yang diterima maupun yang di ketahui langsung oleh penyidik, laporan polisi, berita acara pemeriksaan tersangka, dan berita acara pemeriksaan saksi.

b) Penindakan berupa tindakan hukum yang dilakukan oleh penyidik/penyidik pembantu terhadap orang maupun barang yang ada hubungannya dengan tindak pidana yang terjadi. Penindakan hukum tersebut berupa pemanggilan tersangka dan saksi, penangkapan, penahanan, penggeledahan, dan penyitaan.

c) Pemeriksaan guna mendapatkan keterangan, kejelasan dan keidentikan tersangka dan atau saksi dan atau barang bukti ataupun unsur-unsur tindak pidana yang terjadi sehingga kedudukan dan peranan seseorang maupun barang bukti didalam tindak pidana menjadi jelas dan dituangkan dalam berita acara pemeriksaan yang berwenang melakukan pemeriksaan adalah penyidik dan penyidik pembantu

d) Penyelesaian dan penyerahan berkas perkara, merupakan kegiatan akhir dari proses penyidikan tindak pidana yang dilakukan oleh penyidik dan penyidik pembantu 
Dalam melaksanakan fungsi tersebut aparat penegak hukum tentu harus memperhatikan asas-asas yang menyangkut hak-hak manusia, antara lain :

a) Asas praduga tak bersalah dengan dasar hukum dalam penjelasan umum KUHAP butir ke 3 huruf c dan UU Kehakiman dalam Pasal 8 ayat (1) yaitu setiap orang yang sebagai tersangka, dalam penahanan, di tangkapm dituntut, atau sedang menjalani proses peradilan harus di anggap sebagai subjek yang tidak bersalah sampai ada putusan sah dari pengadilan yang diputus leh hakim melalui sidang menyatakan bahwa orang tersebut telah terbukti elakukan tindak pidana, tetapi dalam kasus yang penulis angkat tersangka atau orang berinisial $\mathrm{S}$ tersebut sudah dianggap sebagai objek dan dipaksa mengakui kesalahannya.

b) Asas persamaan dimuka hukum dengan dasar hukum pasal 27 ayat (1) UUD 1945 yaitu bersikap tidak memandang bulu tidak memihak manapun semua orang harus mendapat perlindungan hukum proses hukum dan penjatuhan hukuman yang sama tidak memandang status social tidak memandang kepetingan perorangan atau kelompok tidak memandang status jabatan politik atau apapun karena hal lain mulai dari dilakukannya penangkapan penahanan dan peradilan tentang apa yang disangkakan kepadanya dan semua harus mendapatkan hak dan perlakuan yang sama yang adil yang sesuai dengan aturan karena dalam undang-undang tidak membedakan orang terbukti disebut dengan kata "barang siapa" arti nya siapa saja sama di muka hukum harus bersifat adil jujur dan tidak memihak semuanya hanya demi satu tujuan yaitu keadilan.

c) Upaya penangkapan penggeledahan dan penahanan terhadap tersangka hanya bisa dilaksanakan oleh atas dasar perintah tertulis dari pejabat yang berwenang dan di beri wewenang oleh amanat undang-undang dengan cara syarat dan ketentuan yang telah di atur. 
d) Tersangka yang ditangkap dan dimintai keterangan mempunyai hak memberikan keterangan dan jawaban secara bebas dalam arti tidak di bawah tekanan paksaan dan berhak setelahnya di proses lebih lanjut ke proses penuntutan oleh penuntut umum ( Pasal 52 KUHAP)

e) Seseorang yang ditangkap, ditahan, dituntut, dan diadili disidang pengadilan oleh karena hal dan alasan tidak jelas dan tidak sah atau oleh kesalahan prosedur dan teknis maka seorang tersangka tersebut dirugikan dan berhak mengajukan ganti rugi serta pembersihan nama baik .

Berdasarkan hasil wawancara Kombespol Hendri Marpaung menjelaskan berapa ada beberapa penyebab atau factor yang membuat perlunya ada bantuan hukum terhadap orang yang berstatus tersangka atau terdakwa seperti sosok mereka saat berhadapan dengan hukum dalam sebuah peradilan atau persidangan adalah sangat lemah dibandingkan pihak yang menjadi lawan mereka yaitu aparat penegak hukum seperti kepolisian jaksa maupun hakim, oleh karena itu mereka dirasa perlu mendapatkan pendaping hukum untuk membrikan bantuan dan dampingan untuk melewati semua proses yang sedang dijalani, apalagi kebanyakan orang awam tidak memiliki pengetahuan yang mendalam mengenai aturan aturan hukum yang ada dan mereka tertekan dalam factor psikologis dan kejiwaan. Bagi sebagian orang untuk mereka berurusan dengan hukum adalah suatu pukulan yang sangat mendalam.

Di dalam hukum di Indonesia kita juga mengenal apa yang disebut dengan praperadilan. Dasar hukum Praperadilan diatur dalam UU No. 8 Tahun 1981 tentang Hukum Acara Pidana (“KUHAP”), khususnya Pasal 1 angka 10, Pasal 77 s/d Pasal 83, Pasal 95 ayat (2) dan ayat (5), Pasal 97 ayat (3), dan Pasal 124. Praperadilan adalah lembaga yang berwenang melakukan dan memeriksa memutus sebuah proses penegakan hukum apakah sah atau tidak sah nya suatu penangkapan penahanan oleh seorang tersangka yang di ajukan atau tersangka yang menggugat praperadialn melalui permintaan tersangka keluarga dia 
maupuun kuasa hukumnya, dan diputus oleh hakim tunggal, jika dalam gugatan tersebut dimenangkan oleh penggugat dan memang terbukti adanya kesalahan prosedr maka penggugat berhak atas ganti rugi pelepasan status tersangka, dikeluarkan dari tahanan, serta rehabilitasi atau pembersihan nama baik. Praperadilan bermaksud melakukan pengawasan horizontal untuk mencegah tindakan hukum upaya paksa yang berlawanan dengan undang-undang.

Setiap segala sesuatu yang di bentuk dan didirikan pasti memiliki maksud dan tujuan atau motivasi tertentu untuk menggapai apa yang di citakan untuk dicapai. Oleh karena itu lah lembaga praperadilan didirikan untuk melakukan sebuah pengawasan dengan tujuan untuk memberikan perlindungan terhadap hak tersangaka d yang terlibat dalam sebuah perkara pidana khususnya, selain itu juga merupakan alat control bagi pelaksanaan tindakan yang dilakukan dengan daasar undang undang oleh para penegak hukum kita. Tujuan utamanya adalah untuk menjamin para aparat untuk bertindak bertanggung jawab sesuai dengan amanah dan ketentuan undang-undang yang berlaku dan menjadi pedoman dalam setiap tindakan yang dilakukan.

Dalam melakukan penulisan ini penulis menyertakan teori perlindungan hukum yang menurut beberapa ahli pemahaman dari teori ini adalah bahwa perlindungan hukum gambaran atau tolak ukur dari sebuah penerapan fungsi hukum demi mewujudkan sebuah cita cita dan tujuan hukum yang satu yaitu sebuah keadilan. Perlindungan hukum yang memberikan perlindungan kepada subjek hukum sesuai dengan aturan hukum yang berlaku, baik secara preventif maupun secara represif, baik secara tertulis maupun tidak tertulis dalam rangka penegakan hukum. Penulis juga melakukan wawancara dengan beberapa praktisi hukum yaitu dengan seorang polisi berpangkat kombespol yang menjabat sebagai direktur reserse di Polda Sumatera Utara. Dalam wawancara tersebut dijelaskan oleh Kombespol Hendri Marpaung mengenai hak dan wewenang penyidik yang mana sudah di tuangkan dan diatur dalam KUHAP. 
Dengan demikian sebagai aparat penegak hukum petugas pun harus melakukan setiap tindakan dengan mengacu kepada aturan yang berlaku.

Kombespol Hendri Marpaung pun memberikan keterangan kepada penulis bahwa institusi kepolisian kini sudah menjadi institusi POLRI yang sipil yang berarti Undang-Undang yang berlaku adalah KUHAP dan PERKAP No 14 Tahun 2012 yang berguna untuk acuan dan sebagai pengawasan dalam anggota dalam pelaksanaan setiap tindakan dan perilakunya terhadap tindakan disiplin dan kode etik profesi. Adapun tindakan yang tidak sesuai dengan aturan yang berlaku yang dilakukan oleh petugas itu adalah oknum. Adapun akibat hukum jika seorang petugas POLRI tidak bertindak sesuai dengan kewenangan nya ada dua yaitu pertama oleh PROPAM berdasarkan PERKAP No 14 Tahun 2012 mengenai kode etik dan yang ke dua yaitu dikenakan hukum positive seperti warga sipil pada umumnya. Tidak jauh berbeda dengan seorang pengacara senior yaitu Pak Munir Fuady, beliau mengatakan bahwa selama beliau menjadi pengacara beliau sering mendapati kasus seperti contoh kasus yang penulis angkat. Menurut beliau dalam perlindungan hak tersangka di Indonesia masih sangat lemah, masih terlalu longgar aturan yang ada untuk melindungi hak tersangka pada praktik penegakan hukum sehingga tidak menimbulkan efek jera dan masih terus terulalng kembali. Dalam praktik seorang penyidik pasti mengharapkan pada saat dilakukan pemeriksaan dan pada saat persidangan di pengadilan adalah keterangn dari seorang tersangka yang dapat dijadikan titik cerah atas penyelesaian perkara tersebut. Dalam memberikan keterangan seorang tersangka hendak tidak di arahkandengan intimidasi atau paksaan secara fisik maupun lisan untuk mndapatkan jawaban sesuai yang diinginkan oleh penyidik. Apabila tersangka berada di bawah tekanan yang akan menimbulkan perasaan takut dan berakhir dengan ketidak terangan dan ketidak jujuran dalam sebuah proses hukum yang pada akhirnya pasti tidak mencapai sebuah keadilan. 
Praperadilan juga merupakan sarana gugatan yang bisa di ajukan oleh tersangka yang dilanggar hak nya tapi hanya sebatas menyangkut prosedur tata cara bertindak atau formil dan tidak masuk terhadap substansi hukum materil. Praperadilan dinilai Pak Munir masih sangat kurang untuk melindungi hak tersangka dalam praktik perlindungan hukum di Indonesia. Dengan demikian dapat dilihat bahwa dalam praktik proses penegakan hukum memang penegakan yang dilakukan oleh aparat seringkali bertentangan dengan aturan terutama merugikan hak tersangka dan tidak menghargai harkat dan martabat manusia seperti dari contoh kasus yang di angkat, masih terjadi pemeriksaan dengan cara kekerasan dan ancaman kekerasan baik yang bersifat fisik maupun nonfisik, dan juga di abaikannya pemberian hak-hak yuridis yang dimiliki oleh tersangka seperti hak memperoleh penasehat hukum, hak mendapat kunjungan sewaktuwaktuoleh penasehat hukum tersangka untuk kepentingan pembelaan dan lain sebagainya. Namun demikian dari segi yuridis normatif KUHAP sebenarnya telah memberikan jaminan perlindungan hak asasi manusia bagi tersangka, dan telah pula memenuhi persyaratan sebagai dasar hukum penyelenggaraan peradilan pidana yang adil (due process of law). Namun KUHAP belum mengatur akibat atau konsekuensi yuridis berupa pembatalan, penyidikan, dakwaan, atau penolakan bahan pembuktian apabila terjadi pelanggaran hakhak yuridis tersangka.

Dengan adanya lembaga praperadilan memang nyatanya tidak ampuh dalam melindungi atau mencegah terjadinya pelanggaran atau kesewenangan penindakan perkara, dalam hal ini hak tersangka seperti yang dimaksud oleh asasubi jus ihi rerrudium dan asas ubi rertidium ibi jus, yang artinya adalah jika dalam hukum sudah memberikan hak hak tertentu maka ada kewenangan untuk menutut dan mendapat hak yang di jamin tadi. Oleh sebab itu perlu nya ada kepedulian dalam melaksanakan amanat undang undang dan disertai oleh rasa bertanggung jawab dari aparat penegak hukum untuk mematuhis segala aturan dan menerapkannya dalam segala sistem hukum agar tercapai keiinginan atau 
cita cita hukm yang di maksud. Sehingga untuk ke depan nya di harapkan tidak ada lagi kejadian serupa seperti sekarang yang masih marak terjadi salah tangkap, salah prosedur, adanya kekerasan fisik maupun non fisik pada tahap penyidikan perkara pidana. Sikap professional harus lebih dikedepankan dalam pelaksanaan tugas harus lebih memusatkan perhatian pada pedoman hukum penyelenggaraan hak asasi manusia hak tersangka dan kesamaan di muka hukum karena setiap subjek hukum tidak boleh di bedakan dan mereka sudah di jamin oleh aturan hukum. Disamping it perlu juga ada keterlibatan dari tokoh masyarakat yang berpengaruh dan lembaga lembaga yang ada untuk ikut serta mengawasi dan memberikan pengetahuan hukum kepada masyarakat.

Terhadap para korban yang dirugikan dengan penyimpangan yang di lakukan oleh aparat secara sewenang-wenang dan tidak sesuai aturan yang ada, maka peneliti menilai beberapa langkah yang bisa di ambil untuk memperjuangkan haknya sebagai tersangka sebagaimana yang telah di atur dalam UndangUndang yaitu dengan cara mengajukan praperadilan atas hal yang tidak benar yang dilakukan oleh penyidik berkaitan dengan proses penangkapan, penyidikan, maupun penetapan tersangka. Untuk melaporkan pelaku kesewenangan ini maka tersangka juga dapat melaporkan tindakan penyimpangan yang di lakukan oleh oknum kepolisian kepada Propam disertai dengan bukti yang ada dan juga dapat mengadukan tindakan tersebut kepada Komnas HAM.

\section{PENUTUP}

\section{A. Kesimpulan}

Berdasarkan contoh kasus yang di atas dibahas mengenai hak tersangka dalam tahap penyidikan dalam penulisan skripsi yang berjudul PERLINDUNGAN HUKUM TERHADAP TERSANGKA PADA TAHAP PENYIDIKAN YANG TIDAK SESUAI DENGAN PASAL 52 KITAB UNDANG-UNDANG HUKUM ACARA PIDANA (contoh kasus: penangkapan tersangka pemilik ribuan rokok illegal). Dapat disimpulkan bahwa dengan putusan dan pertimbangan hakim tunggal 
dalam Putusan Praperadilan No. 10/Pid.Prap/2016/PN.SMG tersebut yang memenangkan tersangka atau dalam hal ini berstatus sebagai pemohon gugatan yang membuktikan bahwa penyidik dalam melaksanakan tugasnya dalam tahap penyidikan masih tidak sesuai dengan aturan yang berlaku dan tidak menghargai hak tersangka pada tahap penyidikan seperti apa yang terjadi dalam contoh kasus tersebut.

Masalah seperti ini masih sering terjadi dalam praktik penegakan hukum, hal seperti ini terjadi karena kurangnya integritas dan rasa tanggung jawab oknum aparat dalam menegakan tugasnya sesuai dengan aturan yang berlaku. Dalam KUHAP maupun PERKAP sudah tegas dan jelas di jabarkan apa saja wewenang, tugas, dan kewajiban bagi aparat dalam melaksanakan tugasnya. Sangat di sayangkan perilaku semacam ini karena dapat merusak citra baik kepolisian republik Indonesia yang seharusnya menjadi pengayom masyarakat. Salah satu upaya hukum yang dapat dilakukan tersangka yang dilanggar haknya dengan menggugat praperadilan, tapi praperadilan ini dinilai masih sangat lemah dalam melindungi hak tersangka di Indonesia dan juga tidak menimbulkan efek jera bagi pelanggar nya terbukti dari terulangnya kasus semacam ini.

\section{B. Saran}

Berdasarkan paparan yang telah dijabarkan oleh penulis, maka penulis megutarakan saran sebagai berikut :

Kasus kesalahan prosedur atas adanya kesewenangan aparat terhadap tersangka memang sangat sering di temui dalam praktik penegakan hukum di Indonesia, namun untuk dapat memperjuangkan hak tersangka seperti apa yang telah tertuang dalam hukum positif di Indonesia kita sebagai masyarakat hukum yang selalu bersentuhan dengan hukum dalam setiap tindakan harus mengetahui apa saja yang menjadi hak kita sebagai warga negara khusus nya dalam hal ini hak sebagai tersangka yang tercantum dalam Pasal 50 sampai 68 KUHAP. Dengan mengetahui hak apa saja yang dimiliki sebagai warga negara maka saat merasa ada hak yang dilanggar oleh aparat penegak hukum kita dapat mengajukan upaya hukum dalam hal ini adalah dengan 
gugatan praperadilan. Dengan proses tersebut setidak nya kita dapat mendapatkan rehabilitasi nama baik dan juga ganti rugi. Sebenarnya sudah ada regulasi dan aturan yang mengatur secara tegas dalam menjamin hak tersangka dan proses penegakan hukum di Indonesia agar berjalan sesuai dengan Undang-Undang yang ada contohnya PERKAP dan pengawasan internal yaitu PROPAM, namun memang oknum polisi masih sering bertindak diluar aturan tersebut. Sudah seharusnya semua proses penegakan harus dilakukan dengan benar agar tidak mencederai hak asasi manusia yang melekat pada setiap individu.

\section{DAFTAR PUSTAKA}

Harahap, Yahya. Pembahasan Permasalahan dan Penerapan KUHAP. (edisi kedua), Jakarta: Sinar

Grafika, 2000.

Makarao, Muhammad Taufik. Hukum Acara Pidana dalam Teori dan Praktek, Jakarta:

Ghalia Indo, 2002.

Alfiah, Ratna Nurul. Praperadilan dan Ruang Lingkupnya, Jakarta: Akademika Pressindo C.V., 1986.

Soekanto, Soerjono. Pengantar Penelitian Hukum, Jakarta: UI Press, 2003.

Soekanto, Soerjono. Penelitian Hukum Normatif Suatu Tujuan Singkat, Jakarta: RajaGrafindo Persada, 2006.

Diantha, I Made Pasek. Metodologi Penelitian Hukum Normatif, Jakarta: Prenada MediaGroup, 2016. 